\title{
Systematic Investigation of the Effects of Macro-elements and Iron on Soybean Plant Response to Fusarium oxysporum Infection
}

\author{
Hongsheng Cai $\mathbb{D}$ *, Nan Tao, and Changhong Guo* \\ Key Laboratory of Molecular and Cytogenetics of Heilongjiang Province, College of Life Science and Technology, Harbin Normal Univer- \\ sity, Harbin 150025, China
}

(Received on April 20, 2020; Revised on August 14, 2020; Accepted on August 18, 2020)

Nutrient manipulation is a promising strategy for controlling plant diseases in sustainable agriculture. Although many studies have investigated the relationships between certain elements and plant diseases, few have comprehensively explored how differing mineral nutrition levels might affect plant-fungal pathogen interactions, namely plant susceptibility and resistance. Here, we systematically explored the effects of the seven mineral elements that plants require in the greatest amounts for normal development on the susceptibility of soybean plants (Glycine max) to Fusarium oxysporum infection in controlled greenhouse conditions. Nitrogen (N) negligibly affected plant susceptibility to infection in the range 4 to $24 \mathrm{mM}$ for both tested soybean cultivars. At relatively high concentrations, phosphorus $(\mathrm{P})$ increased plant susceptibility to infection, which led to severely reduced shoot and root dry weights. Potassium (K), calcium (Ca), magnesium (Mg), sulfur (S), and iron (Fe) induced plant resistance to infection as their concentrations were increased. For $\mathrm{K}$ and $\mathrm{Ca}$, moderate concentrations had a positive effect on plant resistance

\footnotetext{
*Co-corresponding authors.

Hongsheng Cai

Phone)+86-451-88060576

E-mail)hscai@hrbnu.edu.cn

Changhong Guo

Phone) +86-451-88060576

E-mail) kaku_2008@163.com

ORCID

Hongsheng Cai

https://orcid.org/0000-0002-9968-8719

(c) This is an Open Access article distributed under the terms of the Creative Commons Attribution Non-Commercial License (http:// creativecommons.org/licenses/by-nc/4.0) which permits unrestricted noncommercial use, distribution, and reproduction in any medium, provided the original work is properly cited.
}

Articles can be freely viewed online at www.ppjonline.org. to the pathogen, whereas relatively high doses of either element adversely affected plant growth and promoted disease symptoms. Further experiments were conducted, assessing disease suppression by selected combinations of macro-elements and $\mathrm{Fe}$ at screened concentrations, i.e., $\mathrm{K}(9 \mathrm{mM})$ plus Fe $(0.2 \mathrm{mM})$, and $\mathrm{S}(4 \mathrm{mM})$ plus Fe $(0.2 \mathrm{mM})$. The disease index was significantly reduced by the combination of $\mathrm{K}$ plus $\mathrm{Fe}$. In conclusion, this systematic investigation of soybean plant responses to $F$. oxysporum infection provides a solid basis for future environmentally-friendly choices for application in soybean disease control programs.

Keywords : Fusarium oxysporum, macro-element, plant yield, soybean, susceptibility

Handling Editor : Jungkwan Lee

In the soybean plant (Glycine max), Fusarium root rot disease is caused by soil-borne fungi (Fusarium spp.) and is among the most frequently reported plant diseases in China (Chang et al., 2018). This fungal pathogen can affect soybean plants at any stage of development and often causes severe losses in crop yield and quality (Díaz Arias et al., 2013). The infected plants typically show poor emergence from seed and the main visible symptoms of diseased seedlings are brown or black vascular discoloration generally confined to the roots and lower stems. It was estimated that soybean yield losses due to Fusarium root rot were ca. 118.9 million USD in the United States in 2005 alone (Wrather and Koenning, 2006). In recent years, F. oxysporum have become the dominant pathogen responsible for soybean root rot disease in northeastern China ( $\mathrm{Li}$ et al., 2018).

Treating seeds with fungicide is considered an effective management intervention for preventing Fusarium infec- 
tions in commercial fields. However, in most cases, soybean farmers do not implement this practice because the benefit in yield is not worth the costs to apply it, especially as the disease incidence is somewhat weather dependent, namely more likely in cold and wet conditions (Zhang et al., 2010). Both the type of cultivars grown and cultivation practices are also used to deter plant infections by Fusarium, but there are limited resistance resources for Fusarium spp. (Zhang et al., 2013). Some work also suggests beneficial microbes could be used as biocontrol agents for $\mathrm{Fu}-$ sarium root rot in soybean (Al-Ani et al., 2012). However, because these practices are usually labor-intensive, quite costly and not always effective, better strategies are needed to cope with this "unstable" fungal pathogen.

Mineral nutrients are vital factors for normal growth and development in plants. Yield increases for most crops are ascribed in part to their proper nutritional management. Mounting evidence also suggests that mineral elements play key roles in plant resistance to pathogens (Walters and Bingham, 2007). Plants possess preformed defenses such as cell walls, epidermal cuticles, and bark to resist pathogen attack. Plants can also activate basic defense pathways that include the production of reactive oxygen species (ROS), as well as the synthesis of antimicrobial secondary metabolites and pathogenesis-related proteins (van Loon, 2016). These defense processes are closely related to plant metabolism, which is strongly affected by nutritional status. Given the dual functioning of mineral nutrients in crop production and defense against pathogens, it should be possible to manage plant diseases by properly adjusting the contents and combinations of different essential elements.

The objectives of this study were as follows: (1) to assess the effects of seven abundant elements that plants need for normal growth (i.e., $\mathrm{N}, \mathrm{P}, \mathrm{K}, \mathrm{Ca}, \mathrm{Mg}, \mathrm{S}$, and $\mathrm{Fe}$ ) on soybean response to F. oxysporum; (2) to determine the association of those effects with plant biomass production; and (3) to test selected combinations of screened concentrations of elements for disease suppression.

\section{Materials and Methods}

Plant material and growth conditions. Seeds of soybean (Glycine max cv. DS9 and DS7) were sterilized with 75\% ethanol for $3 \mathrm{~min}$ and then washed three times with sterile water. Two seeds were planted per pot that contained only vermiculite, which were supplemented with Hoagland basic nutrient solution (Hoagland and Arnon, 1938). The effect of vermiculite on mineral composition was explored by dipping vermiculite in water for 5 days and then the con- centrations of minerals were measured (Keming, Nanjing). The results were as follows: N, $0.03 \mathrm{mM} ; \mathrm{P}, 0.04 \mathrm{mM}$; , $0.004 \mathrm{mM}$; Ca, $0.05 \mathrm{mM}$; Mg, $0.013 \mathrm{mM}$; S, $0.026 \mathrm{mM}$; and $\mathrm{Fe}, 0.001 \mathrm{mM}$. Compared with concentrations tested in this study, these mineral concentrations are negligible. Different nitrogen $(\mathrm{N})$ concentrations were generated according to Reddy et al. (1996). For phosphorus (P), $\mathrm{KH}_{2} \mathrm{PO}_{4}$ was used to generate different $\mathrm{P}$ regimes. For potassium $(\mathrm{K})$ and calcium $(\mathrm{Ca}), \mathrm{KNO}_{3}$, and $\mathrm{Ca}\left(\mathrm{NO}_{3}\right)_{2}$ were respectively adjusted to generate the corresponding concentrations. $\mathrm{MgSO}_{4}$ was replaced with $\mathrm{Na}_{2} \mathrm{SO}_{4}$ and $\mathrm{MgCl}_{2}$ to generate different magnesium $(\mathrm{Mg})$ and sulfur $(\mathrm{S})$ concentration regimes, respectively. Different concentrations of iron $(\mathrm{Fe})$ were prepared as described (Fourcroy et al., 2014), for which Fe-EDTA was used. The details are listed in Supplementary Table 1 . Plants were grown in a climate chamber with conditions $26^{\circ} \mathrm{C} / 20^{\circ} \mathrm{C}$ and a $16-\mathrm{h} / 8$-h light/dark cycle at $60 \%$ relative humidity.

Fungal culture and infection assays. $F$. oxysporum (isolated from soybean plants in the field and stored in our lab) was cultured on potato-dextrose-agar for 10 days at $25^{\circ} \mathrm{C}$. The inoculation procedure followed Hoffland (Hoffland et al., 2000) with minor modifications made. In brief, spore suspensions for inoculation were prepared by flooding cultures with distilled water, then filtering them through sterile cloth. The final conidia concentration was adjusted to $10^{6}$ conidia/ml. Two-week-old soybean plants were used for all inoculations. Nine plants per treatment were immersed in a spore suspension for $2 \mathrm{~h}$. Then the roots were washed with distilled water and put back into the pots for further growth. Two weeks after inoculation, disease severity was calculated as the percentage of root area showing any brown or black discoloration. Plant height was also measured, and the shoot dry weights and root dry weights recorded for each plant after oven drying for $24 \mathrm{~h}$ at $60^{\circ} \mathrm{C}$.

Data analysis. All experiments were carried out three times. The statistical significance of disease severity differences among samples was analyzed by pairwise comparisons using Dunnett's test. $P<0.05$ was considered significantly different. Lower-case letters indicate results significant for soybean cv. DS9 and upper-case letters indicate results significant for soybean cv. DS7. The same method was used to analyze plant height, shoot dry weight, and root dry weight data. All statistical analyses were performed using the SPSS version 24.0 software program (IBM Corp., Armonk, NY, USA). 
A

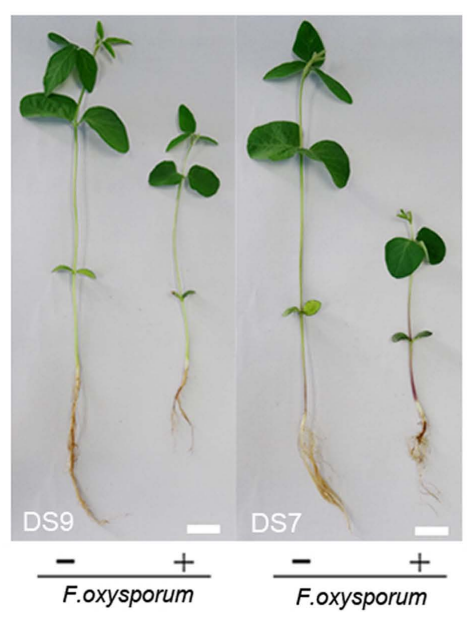

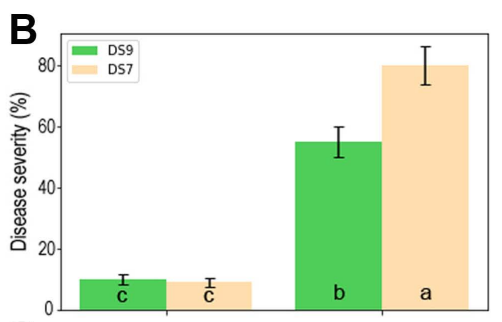

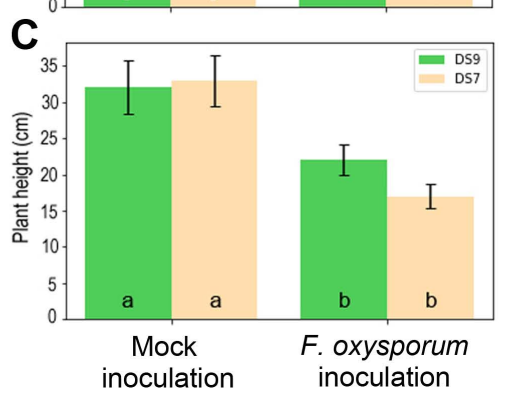

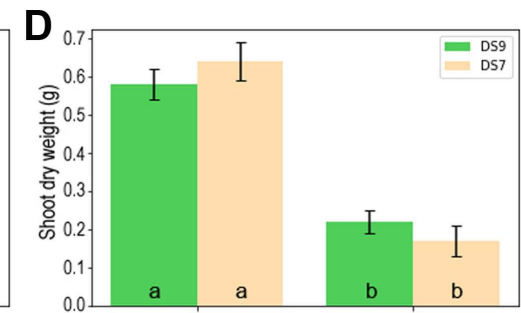

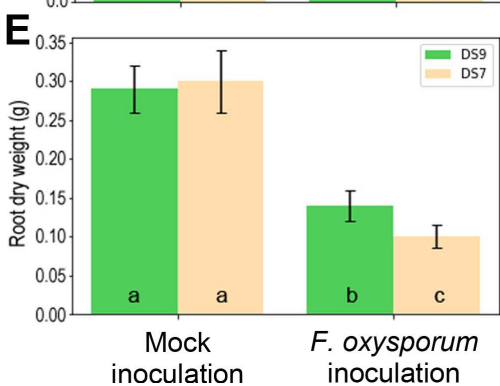

Fig. 1. Soybean-Fusarium oxysporum interactions under normal growth conditions. (A) Soybean plants showed disease symptoms after inoculation for 2 weeks. Scale bars $=3 \mathrm{~cm}$. (B) Effect of $F$. oxysporum on root rot severity. (C) Effect of F.oxysporum on plant height. (D) Effect of $F$. oxysporum on shoot dry weight. (E) Effect of $F$. oxysporum on root dry weight. Bars in B-E panels indicate mean \pm standard errors.

\section{Results}

Soybean-Fusarium interaction assays. A number of soybean cultivars were tested for their resistance to $F$. oxysporum. Different cultivars varied in their disease severity, ranging from $16 \%$ to $96 \%$ (data not shown). Soybean $c v$. DS9 and DS7 displayed moderate and low resistance to $F$. oxysporum respectively (Fig. 1), so they were selected for use in further experiments. For each macro-element, appropriate level was selected for normal plant growth and development.

Responses of soybean plants to N, P, and K supply. NPK fertilizer contains the most important factors contributing to crop production, so exploring their effects on plant resistance and growth parameters will have potential applications. The form of nutritional $\mathrm{N}$ is $\mathrm{NO}_{3}$, and its concentration was set to a minimum of $4 \mathrm{mM}$ to a maximum of $24 \mathrm{mM}$. There was no apparent effect on resistance to $F$. oxysporum in this moderate range of $\mathrm{N}$ concentrations. Both disease severity and plant height remained unchanged for both cultivars, but increased shoot and root dry weights were observed at higher $\mathrm{N}$ concentrations in cultivar DS9, whereas no effect was observed for DS7 (Fig. 2); this effect was significant at a concentration of $\geq 20 \mathrm{mM}$, whereas at $\leq 16 \mathrm{mM}$, the yield of inoculated plants was lower and similar.

The tested concentration of $\mathrm{P}$ ranged from 0.5 to $6 \mathrm{mM}$.
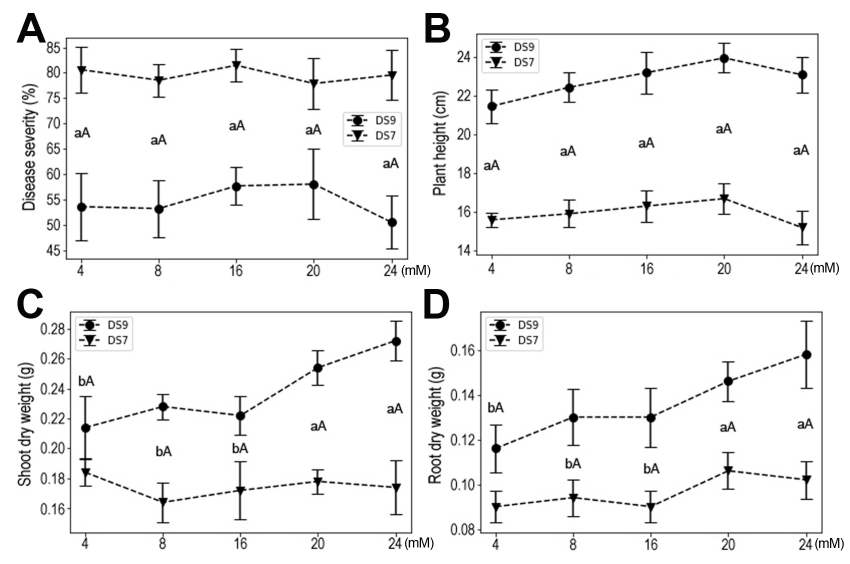

Fig. 2. The effect of $\mathrm{N}$ supply on soybean plants inoculated with Fusarium oxysporum. (A) Disease severity. (B) Plant height. (C) Shoot dry weight. (D) Root dry weight. Data shown are mean \pm standard errors.

High doses of $\mathrm{P}$ increased plant susceptibility to $F$. oxysporum in both cultivars, and this effect was significant at $\geq 2$ $\mathrm{mM}$ (Fig. 3A). Accordingly, plant heights were reduced at higher $\mathrm{P}$ concentrations, but this impact started at a lower concentration of $1 \mathrm{mM}$ (Fig. 3B). A similar pattern was also observed for shoot dry weight and root dry weight responses (Fig. 3C and D).

With more K, disease severity was reduced, but this effect was reversed at the higher concentration of $12 \mathrm{mM}$ in cultivar DS9. Similar trends were also observed for shoot and root dry weights (Fig. 4). These results indicate that K 

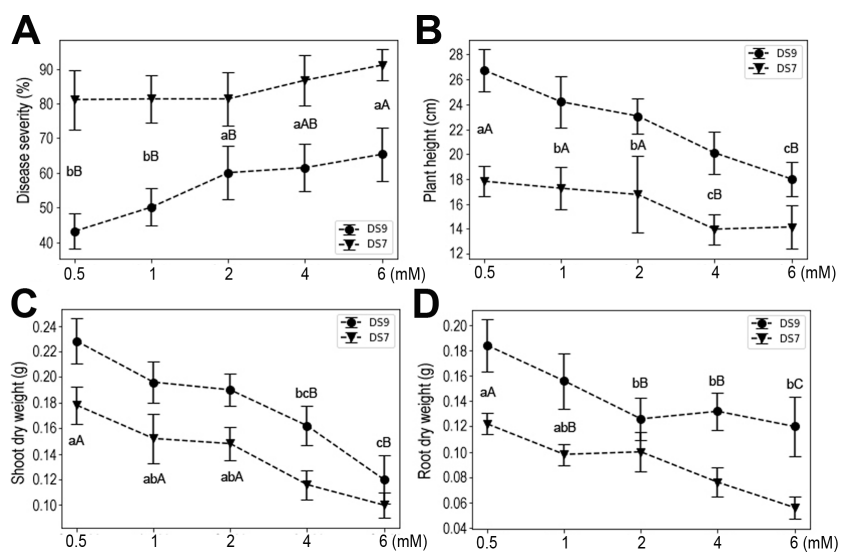

Fig. 3. The effect of $P$ supply on soybean plants inoculated with Fusarium oxysporum. (A) Disease severity. (B) Plant height. (C) Shoot dry weight. (D) Root dry weight. Data shown are mean \pm standard errors.
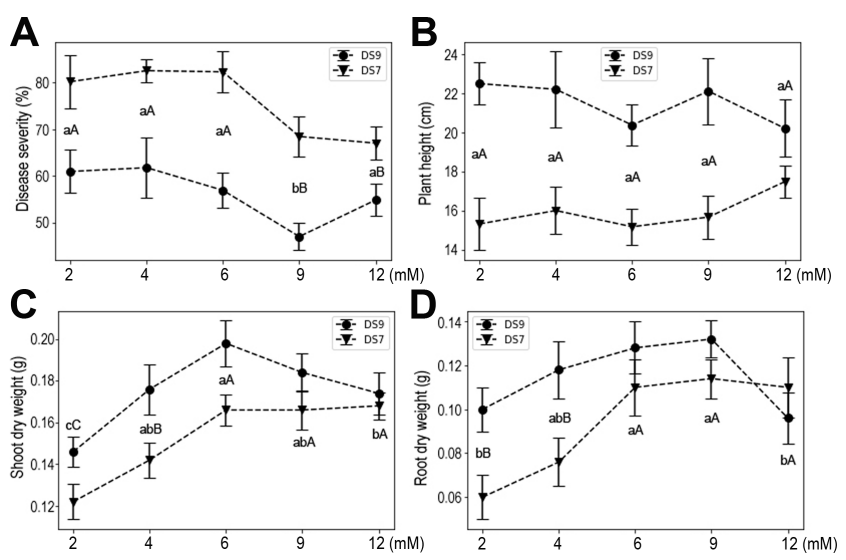

Fig. 4. The effect of K supply on soybean plants inoculated with Fusarium oxysporum. (A) Disease severity. (B) Plant height. (C) Shoot dry weight. (D) Root dry weight. Data shown are mean \pm standard errors.

deficiency negatively affected plant yield and resistance to F. oxysporum, while moderate $\mathrm{K}$ had positive effects on plant growth. Evidently, a high dose of K severely impacted plant growth and resistance to $F$. oxysporum.

Responses of soybean plants to $\mathrm{Ca}, \mathrm{Mg}$, and $\mathrm{S}$ supply. $\mathrm{Ca}, \mathrm{Mg}$, and $\mathrm{S}$ are the group of macronutrients with the second highest quantity demand in plants (Guo et al., 2015; Khan et al., 2013; Song et al., 2008). Multiple roles for these elements in plant physiology and responses to environmental challenge have been reported. In the current experimental system, moderate supply of $\mathrm{Ca}$ increased plant resistance to the fungal pathogen, and also plant heights and yields (Fig. 5). However, when the $\mathrm{Ca}$ concentration
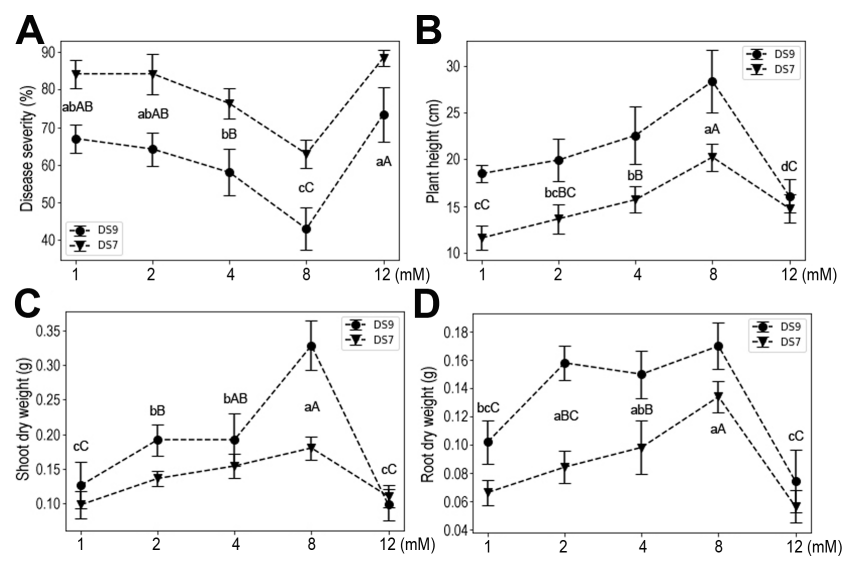

Fig. 5. The effect of Ca supply on soybean plants inoculated with Fusarium oxysporum. (A) Disease severity. (B) Plant height. (C) Shoot dry weight. (D) Root dry weight. Data shown are mean \pm standard errors.
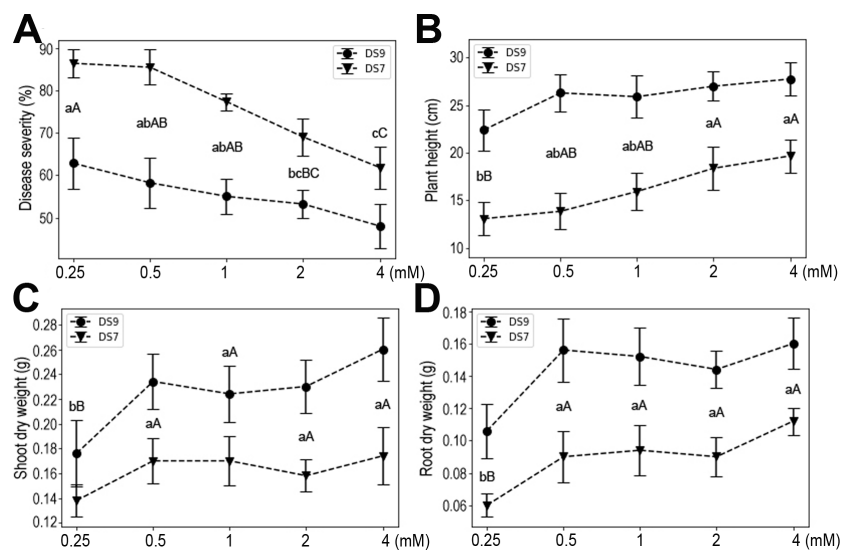

Fig. 6. The effect of $\mathrm{Mg}$ supply on soybean plants inoculated with Fusarium oxysporum. (A) Disease severity. (B) Plant height. (C) Shoot dry weight. (D) Root dry weight. Data shown are mean \pm standard errors.

reached $12 \mathrm{mM}$, plant growth was severely inhibited in both cultivars, as evidenced by the reduced plant height, shoot dry weight, and root dry weight. Moreover, high doses of $\mathrm{Ca}$ also increased plant susceptibility to $F$. oxysporum. These results suggest that $\mathrm{Ca}$ influences both the seedling and pathogen, pointing to complex roles it may play as an important signaling molecule.

Significantly greater resistance of soybean seedlings to $F$. oxysporum was observed at an $\mathrm{Mg}$ concentration of $2 \mathrm{mM}$ in both cultivars (Fig. 6). At this level, plant heights were also significantly improved over lower concentrations. For plant yields (shoot or root dry weight), it seems that a low level of $\mathrm{Mg}(0.5 \mathrm{mM})$ could have positive effects, and this effect was maintained up to $4 \mathrm{mM} \mathrm{Mg}$. 

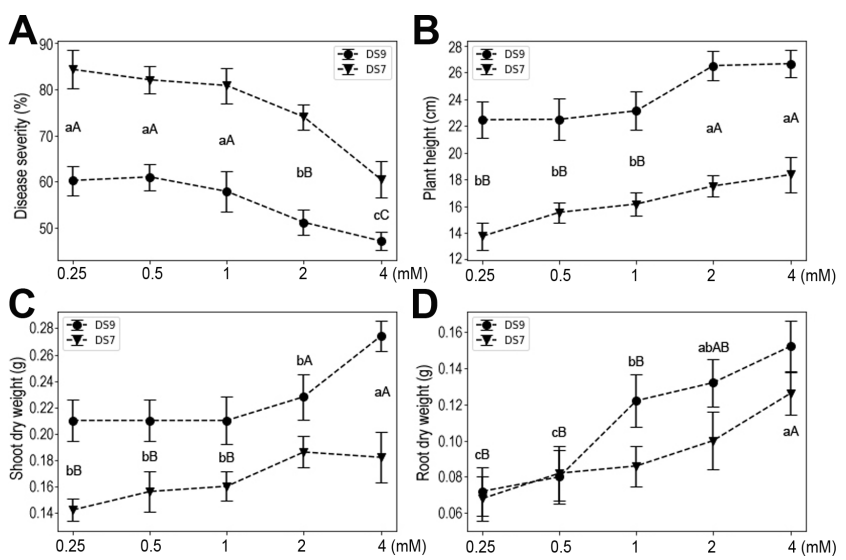

Fig. 7. The effect of S supply on soybean plants inoculated with Fusarium oxysporum. (A) Disease severity. (B) Plant height. (C) Shoot dry weight. (D) Root dry weight. Data shown are mean \pm standard errors.
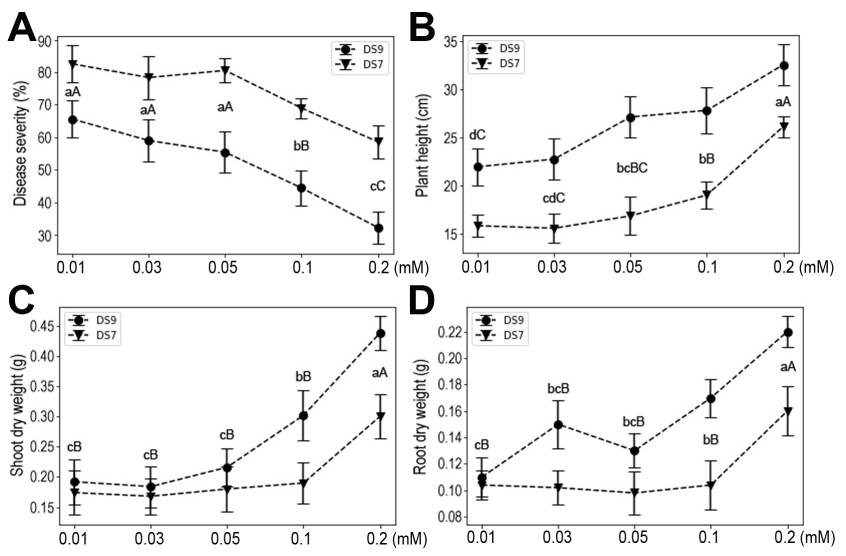

Fig. 8. The effect of Fe supply on soybean plants inoculated with Fusarium oxysporum. (A) Disease severity. (B) Plant height. (C) Shoot dry weight. (D) Root dry weight. Data shown are mean \pm standard errors.

High concentrations of S (either 2 or $4 \mathrm{mM}$ ) significantly improved plant resistance to $F$. oxysporum in both cultivars (Fig. 7). This effect was also apparent via enhanced plant height, with even a moderate amount of S able to stimulate plant height under pathogen infection. Moreover, both shoot and root dry weights were significantly improved with higher concentrations of $\mathrm{S}$, with the latter more sensitive to $\mathrm{S}$ supply.

Responses of soybean plants to Fe supply. Fe is a micronutrient, but a relatively high level is required by plants compared with that for other micro-elements, so we also investigated the effects of Fe supply on plant responses to infection. Susceptibility of both cultivars to $F$. oxysporum did not change at low concentrations of $\mathrm{Fe}(0.01,0.03$, or

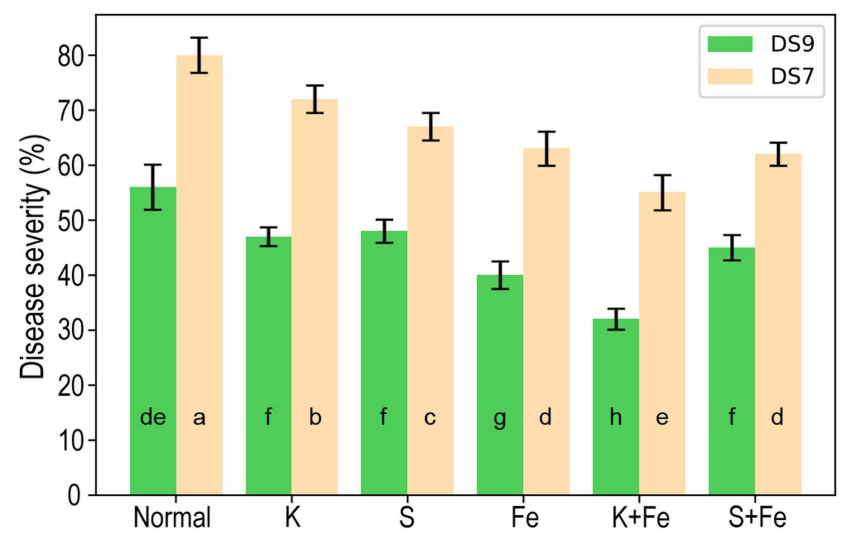

Fig. 9. The effect of combination of optimized concentrations of K, S, and Fe supply on soybean plants inoculated with Fusarium oxysporum. Data shown are mean \pm standard errors.

$0.05 \mathrm{mM})$, whereas at high levels $(0.1$ and $0.2 \mathrm{mM})$ it was significantly decreased (Fig. 8A). At $0.1 \mathrm{mM} \mathrm{Fe}$, disease severity was significantly decreased vis-à-vis lower concentrations. Notably, when the concentration of Fe reached $0.2 \mathrm{mM}$, an even more pronounced reduction in disease severity occurred. Accordingly, similar patterns characterized the plant height and shoot and root dry weight responses (Fig. 8B-D). These results indicate that moderate-to-high levels of Fe significantly enhance soybean resistance to $F$. oxysporum and soybean growth parameters (i.e., height, shoot and root dry weights).

Combination of screened concentrations of elements for disease suppression. We further tested the potential for disease suppression by combinations of elements at screened concentrations. Combinations of $\mathrm{K}(9 \mathrm{mM})$ plus $\mathrm{Fe}(0.2 \mathrm{mM})$, and $\mathrm{S}(4 \mathrm{mM})$ plus $\mathrm{Fe}(0.2 \mathrm{mM})$ were tested. The disease index was significantly reduced by the combination of $\mathrm{K}$ plus Fe compared with $9 \mathrm{mM} \mathrm{K}$ or $0.2 \mathrm{mM} \mathrm{Fe}$ treatments, whereas no significant difference was observed for the combination of S plus Fe compared with $4 \mathrm{mM} \mathrm{S}$ or $0.2 \mathrm{mM} \mathrm{Fe}$ (Fig. 9). This trend was observed for both cultivars.

\section{Discussion}

Plant fungal pathogens represent one of the major factors affecting global crop yields (van Esse et al., 2020). Planting resistant cultivars and applying fungicides are the most frequently used strategies used for controlling diseases. However, both methods have their limitations, e.g., long breeding cycles for producing resistant cultivars, rapid pathogen evolution to escape host defenses, and environmental problems caused by fungicide application (Jørgensen et 
al., 2017; van Bruggen and Finckh, 2016; van Esse et al., 2020). Macro-elements are an essential ingredient for the normal growth and development of plants, and they can substantially impact plant immune responses (Datnoff et al., 2007). While extensive studies have ascertained the effects of particular elements on plant resistance to individual pathogens (Dordas, 2008), few studies have systematically explored the relationships between macro-elements and plant responses to one or more specific fungal pathogens.

In this study, using the soybean and $F$. oxysporum interaction system, we systematically investigated the effects of the seven mineral elements that plants require in the greatest amounts for normal development on plant responses to pathogen infection. The elements had different effects on plant responses to infection in both tested soybean cultivars. $\mathrm{N}$ had no discernable effects on plant resistance to infection, but $\mathrm{P}$ increased plant susceptibility to infection, whereas $\mathrm{K}, \mathrm{Ca}, \mathrm{Mg}, \mathrm{S}$, and $\mathrm{Fe}$ each induced plant resistance to infection. These effects were corroborated by the measured plant weight, shoot and root dry weights, which are widely used indicators of plant growth status. Although both DS9 and DS7 cultivars showed similar trends in response to $F$. oxysporum infection in different nutritional conditions, they did differ in the presence of high levels of certain elements, i.e., $\mathrm{N}$ and $\mathrm{K}$. This indicates that there are genetic factors determining the use of certain elements.

The relationship between nutrition and disease is complex, and often depends on specific pathogens and their associated hosts (Verbon et al., 2017). N, P, and K are the most commonly used fertilizers in agriculture. The role of $\mathrm{N}$ in disease development is somewhat contradictory, however, and the forms of nitrogen (i.e., $\mathrm{NO}_{3}$ vs. $\mathrm{NH}_{4}$ ) can also have different effects on diseases of plants (Mur et al., 2017). In our study, $\mathrm{NO}_{3}^{-}$was used to test for disease development in soybean. The results showed that $\mathrm{N}$ levels did not seem to influence plant disease development, though adding more $\mathrm{N}$ did increase yields (shoot and root dry weights) of cultivar DS9. The effects of $\mathrm{P}$ on disease resistance are also reportedly inconsistent (Walters and Bingham, 2007). An increased susceptibility of soybean plants to $F$. oxysporum was observed in our study. Having vital biochemical functions in plants, $\mathrm{K}$ was found to decrease the incidence of diseases in most studies investigating this (Wang et al., 2013), a trend also found in our study. However, a relatively high concentration of K (12 $\mathrm{mM}$ ) appeared to increase soybean plant susceptibility to $F$. oxysporum.

Calcium is an important component of middle lamella and cell walls, and plays vital roles in membrane functioning and signal transduction (Thor, 2019). As such, $\mathrm{Ca}$ and the Ca signaling process are among the first actors involved in setting up a plant's response to biotic interactions (Aldon et al., 2018). With a greater Ca concentration, soybean plants showed a trend of increased resistance; however, a high level of $\mathrm{Ca}$ elicited a similar response to a low level of $\mathrm{Ca}$. This result indicates a complex participation of $\mathrm{Ca}$ in plant growth and responses to diseases. As a component of chlorophyll, $\mathrm{Mg}$ is essential for photosynthesis in plants. Moreover, $\mathrm{Mg}$ also acts as a cofactor of many enzymes, and it was reported to reduce disease severity in several crops (Guo et al., 2015; Huber and Jones, 2012). Likewise, reduced susceptibility of soybean plants to $F$. oxysporum was observed in the present study. It has long been known that applying S can control plant diseases, and both foliarand soil-applied $\mathrm{S}$ was found to increase resistance of different crops to a number of pathogens (Bloem et al., 2015). In our study system, S significantly increased soybean plant resistance to $F$. oxysporum. Interestingly, compared with plant height and shoot dry weight, it was root dry weight that was more sensitive to the added S content. Although the concept of S-induced resistance has been put forward, the precise mechanisms of $\mathrm{S}$ operating on either side of the plant and pathogen interaction remain unknown (Bloem et al., 2015; Bollig et al., 2013). Fe is an essential nutrient for most living organisms and its role in plant-microbe interactions has been extensively studied (Aznar et al., 2015). Fe plays a dual role in this system, on the one hand catalyzing the formation of ROS that plant hosts may use to defend against pathogens, and on the other hand, possibly hastening invasion of plant tissues by necrotrophic pathogens via ROS-mediated cell death (Verbon et al., 2017). In our study, Fe significantly enhanced soybean plant resistance to $F$. oxysporum. Previous studies also showed enhanced resistance to several pathogens on Fe addition, suggesting it has potential applications in agriculture.

It is well known that nutrient deficiency can limit plant productivity, and nutrients can become toxic in excess. However, plants have developed various strategies to maintain nutrient homeostasis; thus, they are more resistant to relatively high levels of nutrients (Kehr, 2013). High levels of elements may affect plants, microbes, and their interactions. Soil microbes are sensitive to nutrient inputs (Leff et al., 2015). In this study, we tested whether ions used in large amount can have a negative effect on a pathogen. F. oxysporum was grown on Fusarium minimal medium (Correll et al., 1987) with selected composition of tested elements. Relatively high levels of $\mathrm{Ca}(12 \mathrm{mM})$ and $\mathrm{S}(4 \mathrm{mM})$ had significant inhibitory effects on F. oxysporum growth (26.11\% and $34.68 \%$ respectively). For other elements, there was no significant inhibitory effect. 
This result together with the observed effect of minerals on plant growth and development give us opportunities for environmentally-friendly disease control strategies in the future.

Appropriate adjustment of nutritional levels in a systematic way would not only maintain proper growth, but also enhance plant immunity and resistance to diseases. For application purposes, we selected the optimized concentrations of three elements, $\mathrm{K}, \mathrm{S}$, and $\mathrm{Fe}$, to explore their combinational effects on disease suppression. For $\mathrm{K}$ plus Fe, a significantly reduced disease index was observed, whereas no better disease suppression effect was observed following treatment with S plus Fe compared with treatment by these elements individually. This reflects complex interactions between nutritional elements, and also elements and plant absorption. More experiments are required to understand these intricate processes.

In conclusion, the present study is, to our knowledge, the first systematic investigation of soybean plant responses to $F$. oxysporum attack under different nutrition levels of macro-elements. The results could be relevant to controlling other pathogens in soybean, and by combining such data, we hope to develop a better and friendlier nutritional management strategy for plant disease control in the future.

\section{Acknowledgments}

This study was supported by The National Key Research and Development Program of China (2017YFD0101303); Youth Foundation of Harbin Normal University (KGB201217); Programs for Science and Technology Development of Heilongjiang Province, China (GA18B104); Science and Technology Achievement Cultivation Project of Heilongjiang Education Department (TSTAU-R2018008).

\section{Electronic Supplementary Material}

Supplementary materials are available at The Plant Pathology Journal website (http://www.ppjonline.org/).

\section{References}

Al-Ani, R. A., Adhab, M. A., Mahdi, M. H. and Abood, H. M. 2012. Rhizobium japonicum as a biocontrol agent of soybean root rot disease caused by Fusarium solani and Macrophomina phaseolina. Plant Protect. Sci. 48:149-155.

Aldon, D., Mbengue, M., Mazars, C. and Galaud, J.-P. 2018. Calcium signalling in plant biotic interactions. Int. J. Mol. Sci. 19:665.

Aznar, A., Chen, N. W. G., Thomine, S. and Dellagi, A. 2015. Immunity to plant pathogens and iron homeostasis. Plant Sci.
240:90-97.

Bloem, E., Haneklaus, S. and Schnug, E. 2015. Milestones in plant sulfur research on sulfur-induced-resistance (SIR) in Europe. Front. Plant Sci. 5:779.

Bollig, K., Specht, A., Myint, S. S., Zahn, M. and Horst, W. J. 2013. Sulphur supply impairs spread of Verticillium dahliae in tomato. Eur. J. Plant Pathol. 135:81-96.

Chang, X., Dai, H., Wang, D., Zhou, H., He, W., Fu, Y., Ibrahim, F., Zhou, Y., Gong, G., Shang, J., Yang, J., Wu, X., Yong, T., Song, C. and Yang, W. 2018. Identification of Fusarium species associated with soybean root rot in Sichuan Province, China. Eur. J. Plant Pathol. 151:563-577.

Correll, J. C., Klittich, C. J. R. and Leslie, J. F. 1987. Nitrate nonutilizing mutants of Fusarium oxysporum and their use in vegetative compatibility tests. Phytopathology 77:1640-1646.

Datnoff, L. E., Elmer, W. H. and Huber, D. M. 2007. Mineral nutrition and plant disease. APS Press, St. Paul, MN, USA. 278 pp.

Díaz Arias, M. M., Leandro, L. F. and Munkvold, G. P. 2013. Aggressiveness of Fusarium species and impact of root infection on growth and yield of soybeans. Phytopathology 103:822832.

Dordas, C. 2008. Role of nutrients in controlling plant diseases in sustainable agriculture: a review. Agron. Sustain. Dev. 28:3346.

Fourcroy, P., Sisó-Terraza, P., Sudre, D., Savirón, M., Reyt, G., Gaymard, F., Abadía, A., Abadia, J., Álvarez-Fernández, A. and Briat, J.-F. 2014. Involvement of the ABCG37 transporter in secretion ofscopoletin and derivatives by Arabidopsis roots in response toiron deficiency. New Phytol. 201:155-167.

Guo, W., Chen, S., Hussain, N., Cong, Y., Liang, Z. and Chen, K. 2015. Magnesium stress signaling in plant: just a beginning. Plant Signal. Behav. 10:e992287.

Hoagland, D. R. and Arnon, D. I. 1938. Growing plants without soil by the water-culture method. Circ. Calif. Agric. Exp. Stn. 3:346-347.

Hoffland, E., Jeger, M. J. and van Beusichem, M. L. 2000. Effect of nitrogen supply rate on disease resistance in tomato depends on the pathogen. Plant Soil 218:239-247.

Huber, D. M. and Jones, J. B. 2012. The role of magnesium in plant disease. Plant Soil 368:73-85.

Jørgensen, L. N., van den Bosch, F., Oliver, R. P., Heick, T. M. and Paveley, N. D. 2017. Targeting fungicide inputs according to need. Annu. Rev. Phytopathol. 55:181-203.

Kehr, J. 2013. Systemic regulation of mineral homeostasis by micro RNAs. Front. Plant Sci. 4:145.

Khan, M. I. R., Asgher, M., Iqbal, N. and Khan, N. A. 2013. Potentiality of sulphur-containing compounds in salt stress tolerance. In: Ecophysiology and responses of plants under salt stress, eds. by P. Ahmad, M. M. Azooz and M. N. V. Prasad, pp. 443-472. Springer-Verlag, New York, NY, USA.

Leff, J. W., Jones, S. E., Prober, S. M., Barberán, A., Borer, E. T., Firn, J. L., Harpole, W. S., Hobbie, S. E., Hofmockel, K. S., Knops, J. M., McCulley, R. L., La Pierre, K., Risch, A. C., 
Seabloom, E. W., Schütz, M., Steenbock, C., Stevens, C. J. and Fierer, N. 2015. Consistent responses of soil microbial communities to elevated nutrient inputs in grasslands across the globe. Proc. Natl. Acad. Sci. U. S. A. 112:10967-10972.

Li, Y., Zhao, T., Hua, G. K. H., Xu, L., Liu, J., Li, S., Huang, H. and Ji, P. 2018. Pathogenicity and genetic diversity of Fusarium oxysporum causing soybean root rot in northeast China. $J$. Agric. Sci. 10:13-23.

Mur, L. A. J., Simpson, C., Kumari, A., Gupta, A. K. and Gupta, K. J. 2017. Moving nitrogen to the centre of plant defence against pathogens. Ann. Bot. 119:703-709.

Reddy, A. R., Reddy, K. R., Padjung, R. and Hodges, H. F. 1996. Nitrogen nutrition and photosynthesis in leaves of Pima cotton. J. Plant Nutr. 19:755-770.

Song, W. Y., Zhang, Z. B., Shao, H. B., Guo, X. L., Cao, H. X., Zhao, H. B., Fu, Z. Y. and Hu, X. J. 2008. Relationship between calcium decoding elements and plant abiotic-stress resistance. Int. J. Biol. Sci. 4:116-125.

Thor, K. 2019. Calcium-nutrient and messenger. Front. Plant Sci. $10: 440$.

van Bruggen, A. H. C. and Finckh, M. R. 2016. Plant diseases and management approaches in organic farming systems. Annu. Rev. Phytopathol. 54:25-54.

van Esse, H. P., Reuber, T. L. and van der Does, D. 2020. Genetic modification to improve disease resistance in crops. New Phytol. 225:70-86.

van Loon, L. C. 2016. The intelligent behavior of plants. Trends Plant Sci. 21:286-294.

Verbon, E. H., Trapet, P. L., Stringlis, I. A., Kruijs, S., Bakker, P. A. H. M. and Pieterse, C. M. J. 2017. Iron and immunity. Annu. Rev. Phytopathol. 55:355-375.

Walters, D. R. and Bingham, I. J. 2007. Influence of nutrition on disease development caused by fungal pathogens: implications for plant disease control. Ann. Appl. Biol. 151:307-324.

Wang, M., Zheng, Q., Shen, Q. and Guo, S. 2013. The critical role of potassium in plant stress response. Int. J. Mol. Sci. 14:7370-7390.

Wrather, J. A. and Koenning, S. R. 2006. Estimates of disease effects on soybean yields in the United States 2003 to 2005. J. Nematol. 38:173-180.

Zhang, J. X., Xue, A. G., Cober, E. R., Morrison, M. J., Zhang, H. J., Zhang, S. Z. and Gregorich, E. 2013. Prevalence, pathogenicity and cultivar resistance of Fusarium and Rhizoctonia species causing soybean root rot. Can. J. Plant Sci. 93:221236.

Zhang, J. X., Xue, A. G., Zhang, H. J., Nagasawa, A. E. and Tambong, J. T. 2010. Response of soybean cultivars to root rot caused by Fusarium species. Can. J. Plant Sci. 90:767-776. 